\title{
KEDALAMAN LUBANG INOKULASI DAN UKURAN DIAMETER POHON UNTUK PEMBENTUKAN GUBAL GAHARU PADA TANAMAN Aquilaria malaccensis Lamk.
}

\author{
(The Depth of Inoculation Hole and The Diameter Size of Trees To Form Sapwood of \\ Agarwood in The Plant of Aquilaria malaccensis lamk.)

\section{Suci Indah Sari, Abdurrani muin, Rosa Suryantini} \\ Fakultas Kehutanan Universitas Tanjungpura. Jalan Imam Bonjol Pontianak 78124 \\ Email: suciindahsari086@gmail.com
}

\begin{abstract}
Research on the induction of the sapwood of agarwood has been extensively studied, but this has not yet resulted in the dept standard of hole of inoculation and the diameter of trees in order to produce the best sapwood. Therefore, this study aimed to study the depth of the effective inoculation hole to accelerate the formation of agarwood cambium or sapwood in various tree diameters, and to know the interaction of agarwood induction. This research was conducted in Sekadau Hilir district. The design of this research was a nested method. The treatment consisted of tree diameter (i.e., $11.46 \mathrm{~cm}, 16.56 \mathrm{~cm}$, and $24.20 \mathrm{~cm}$ ) as the main factor, while the depth of the inoculation hole (i.e., $1 \mathrm{~cm}, 2 \mathrm{~cm}, 3 \mathrm{~cm}, 4 \mathrm{~cm}$, and $5 \mathrm{~cm}$ ) was the second nesting factor. The hole spacing was $15 \mathrm{~cm}$, which was in each treatment, the depth of the inoculation hole was repeated 5 times. The number of holes consisted of 75. In which the depth of inoculation hole was $3 \mathrm{~cm}$ producing an infection on area of $485.13 \mathrm{~cm}^{2}$, brown, and with strong aroma. Tree diameter of $11.46 \mathrm{~cm}$ produced $872.92 \mathrm{~cm}^{2}$ of infected area, blackish brown, and with strong aroma. However, the interaction of tree diameter and the dept of hole was not significant toward the area of agarwood infection formed.
\end{abstract}

Keyword: Agarwood, Aquilaria malaccensis, inoculation

\section{PENDAHULUAN}

Gubal gaharu merupakan sumber daya alam yang termasuk sebagai Hasil Hutan Bukan Kayu (HHBK). Berdasarkan Peraturan Menteri Kehutanan No P.35/Menhut-II/2007 telah ditetapkan jenis-jenis HHBK yang terdiri dari 9 kelompok HHBK yang terdiri dari 557 spesies tumbuhan dan hewan (Anonim 2007). Berbagai jenis pohon hutan penghasil gubal gaharu sebagian besar sudah dibalak untuk dimanfaatkan dan diperdagangkan. Zhang et al. (2014) menyatakan bahwa gaharu diproduksi oleh spesies Aquilaria spp., Wikstroemia spp., Gonystylus spp., Aetoxylon sp., dan Enkleia sp. dari famili
Thymelaeaceae yang mengalami pelukaan atau terinfeksi oleh cendawan.

Beberapa jenis pohon yang berpotensi sebagai penghasil gubal gaharu dengan kualitas yang baik dengan jual tinggi adalah A. malaccensis (Siran 2010). Gubal gaharu dapat digunakan sebagai bahan baku industri parfum, dupa dan obat-obatan, karena manfaatnya yang begitu banyak, maka perlu dilakukan peningkatan produksi, sekaligus untuk melindungi ragam pohon penghasil gaharu di Indonesia (Mucharromah 2010). Menurut Assosiasi Gaharu Indonesia (ASGARIN 2009) dalam Muin dkk, (2017) harga gaharu di Indonesia berkisar antara Rp. 15.000.000,- sampai dengan Rp. 
$30.000 .000,-/ \mathrm{kg}$ tergantung tingkat mutunya. Jika setiap pohon yang sudah mencapai umur 8-10 tahun bisa menghasilkan 3-5 kg gubal gaharu, maka setiap pohon akan diperoleh pendapatan sekitar Rp. 45.000.000,- sampai dengan Rp. 150.000.000,-/pohon. Terbentuknya gaharu ditandai dengan perubahan warna di sekitar luka. Perubahan warna kayu dari putih menjadi coklat kehitaman adalah gejala awal pembentukan senyawa gaharu dan ketika pohon terinfeksi oleh cendawan mengeluarkan aroma yang wangi bila dibakar (Sumadiwangsa dan Zulnely 1999).

Pohon gaharu meskipun sudah banyak tersedia namun hasil yang diperoleh dari gaharu tersebut masih cukup rendah. Hal ini dikarenakan untuk menghasilkan gaharu masyarakat masih menggunakan cara-cara tradisional seperti dengan menakik, memahat, dan memasang pasak pada setiap batang pohon gaharu. Selain dengan cara tersebut masyarakat juga menggunakan gula aren yang dioleskan di sekitar bagian batang yang dilukai meskipun terbentuknya gubal gaharu membutuhkan waktu yang cukup lama (Muin dkk, 2017). Proses untuk mempercepat terbentuknya gubal gaharu, sudah dilakukan inokulasi cendawan dengan menginokulasikan pohon pembentuk gubal gaharu. Hasil penelitian Try dkk, (2017) menunjukkan bahwa ternyata ukuran diameter pohon $27 \mathrm{~cm}$ dengan jarak lubang inokulasi 5 $\mathrm{cm}$ merupakan yang terbaik dalam hal pembentukan gubal gaharu. Namun jika dilihat dari ukuran diameter pohon gaharu yang terdapat di lapangan, maka hasil penelitian tersebut belum dapat dijadikan acuan untuk semua ukuran diameter pohon. Permasalahannya karena sampai sekarang ini belum ada petunjuk kedalaman lubang inokulasi berapa sentimeter yang terbaik untuk setiap ukuran diameter pohon gaharu. Apakah ada hubungan antara kedalaman lubang inokulasi dengan ukuran diameter pohon gaharu dalam pembentukan gubal gaharu tersebut. Atas dasar permasalahan tersebut, maka perlu dilakukan penelitian kedalaman lubang inokulasi pada berbagai ukuran diameter pohon gaharu, agar dapat ditentukan kedalaman lubang inokulasi yang terbaik untuk mempercepat pembentukan gubal gaharu sesuai dengan ukuran diameter pohon. Tujuan penelitian adalah mengkaji pengaruh kedalaman lubang inokulasi yang efektif untuk mempercepat terbentuknya gubal gaharu pada berbagai ukuran diameter pohon dan mengetahui interaksi kedalaman lubang inokulasi dan ukuran diameternya. Hasil penelitian ini diharapkan dapat digunakan sebagai acuan untuk mempercepat proses terbentuknya gubal gaharu dengan kedalaman lubang inokulasi yang efektif pada setiap ukuran diameter pohon.

\section{METODE PENELITIAN}

Penelitian dilakukan pada tanaman Aquilaria malaccensis di Kabupaten Sekadau Hilir, dengan waktu 6 minggu setelah inokulasi. Tahap pertama menentukan titik-titik pengeboran pohon gaharu ditandai dengan spidol, Selanjutnya pohon dibor dengan 
menggunakan mesin bor dengan kedalaman yang sudah ditentukan. Pengeboran dilakukan kearah vertikal dengan jarak antara lubang $15 \mathrm{~cm}$ dan arah horizontal dengan 5 ulangan, kemudian memasukan cairan inokulan yang didapatkan dari hasil pembuatan teman (Fusarium sp.) dengan jarum sutik ke dalam lubang bor, setelah itu, lubang ditutup dengan lilin kemudian disemprot dengan alkohol dan diberi label. Seminggu kemudian dilakukan pengecakan keadaaan lubang inokulasi yang sudah dilakukan di pohon gaharu sampai minggu keempat, minggu kelima dilakukan pengecekan hasil awal, dan minggu keenam dilakukan pengecekan hasil akhir dengan penggambilan data berupa luas area lubang yang terinfeksi, warna, dan aroma yang membentuk gaharu. Pengambilan data berupa luas yaitu dengan mengikis kulit batang pohon gaharu setelah itu mengukur luas arah vertikal dan arah horizontal. Pengambilan data warna dengan penentuan sistem skoring $0=$ putih, $1=$ putih kecoklatan, 2=coklat, $3=$ coklat kehitaman (Putri 2007) dan pengambilan data aroma dengan membakar serpihan gubal gaharu yang sudah terbentuk dengan penentuan sistem skoring $0=$ tidak wangi, $1=$ bau tidak kuat, $2=$ bau kuat, 3=bau sangat kuat (Badan Standarisasa Nasional 1999).

Penelitian menggunakan metode percobaan faktorial tersarang (nested faktorial design) rancangan acak lengkap (RAL) dengan perlakuan penelitian terdiri dari : diameter pohon $11,46 \mathrm{~cm}$ (D1), 16,56 cm (D2), 24,20 cm (D3) sebagai faktor utama. Sebagai faktor kedua yang tersarang kedalam faktor utama diameter pohon berupa kedalaman lubang inokulasi yang terdiri dari $1 \mathrm{~cm}(\mathrm{~K} 1), 2 \mathrm{~cm}(\mathrm{~K} 2), 3 \mathrm{~cm}(\mathrm{~K} 3), 4$ cm (K4), $5 \mathrm{~cm}$ (K5). Setiap perlakuan kedalaman lubang inokulasi diulang sebanyak 5 kali dengan jarak lubang 15 $\mathrm{cm}$, sehingga jumlah lubang inokulasi 3 x 5 x $5=75$ lubang.

Data yang dikumpulkan selama 6 minggu di lapangan berupa luas area yang terinfeksi pengolahan data menggunakan program exel, warna, dan aroma yang membentuk gubal gaharu.

\section{HASIL DAN PEMBAHASAN}

Berdasarkan hasil penelitian yang berjudul kedalaman lubang inokulasi dan ukuran diameter pohon untuk pembentukan gubal gaharu pada tanaman Aquilaria malaccensis yang dilakukan di Kabupaten Sekadau Hilir selama 6 minggu diperoleh hasil sebagai berikut :

\section{Luas Area Lubang yang Terinfeksi}

Luas area lubang yang terinfeksi merupakan sebaran gaharu yang terinfeksi di sekitar lubang inokulasi pohon gaharu. Hasil analisis ragam luas area lubang inokulasi pohon gaharu yang terinfeksi dapat dilihat pada Tabel 1 . Luas area lubang inokulasi pohon gaharu yang terinfeksi pada setiap lubang inokulasi tersebut dapat dilihat pada Gambar 1. 


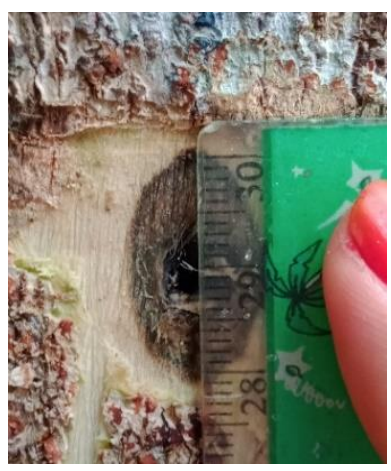

(a)

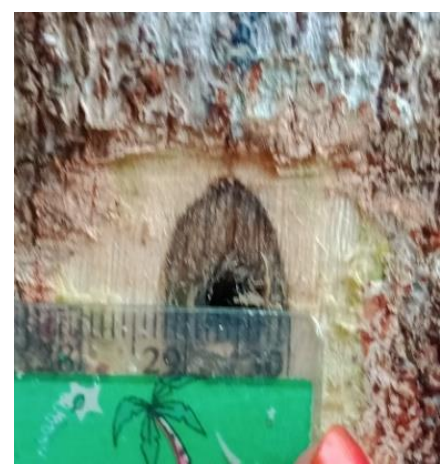

(b)

Gambar 1. Pengukuran Arah Vertikal (a), dan Arah Horizontal (b) (Vertical direction measurement (a), and Horizontal direction $(b)$ )

Tabel 1. Analisis Ragam Pengaruh Luas Area Lubang yang Terinfeksi pada Perlakuan Diamter Pohon dan Kedalaman Lubang Inokulasi serta Interaksinya (Analysis of Variance Effect of infected hole area on the treatment of tree diameter and depth of the inoculation hole and its interactions)

\begin{tabular}{|c|c|c|c|c|c|c|}
\hline \multirow{2}{*}{ Sk } & \multirow{2}{*}{ DB } & \multirow{2}{*}{$\mathrm{Jk}$} & \multirow{2}{*}{ KT } & \multirow{2}{*}{$\mathrm{FH}$} & \multicolumn{2}{|c|}{ F.Tabel } \\
\hline & & & & & 0,01 & 0,05 \\
\hline Diameter (D) & 2 & 977,1 & 488,55 & $20,87^{* *}$ & 4,98 & 3,15 \\
\hline $\begin{array}{l}\text { Kedalaman Lubang } \\
(\mathrm{K})\end{array}$ & 4 & 333,86 & 83,47 & $3,57^{*}$ & 3,65 & 2,53 \\
\hline $\begin{array}{l}\text { Interaksi (dk) } \\
\text { Galat }\end{array}$ & $\begin{array}{c}8 \\
60\end{array}$ & $\begin{array}{c}85,52 \\
1404,25\end{array}$ & $\begin{array}{l}10,69 \\
23,40\end{array}$ & $0,46^{\text {tn }}$ & 2,82 & 2,1 \\
\hline Total & 74 & 2800,73 & $\mathrm{KK}=$ & $22 \%$ & & \\
\hline
\end{tabular}

Keterangan : $* *=$ sangat nyata (signifikan) pada taraf $1 \%, *=$ berbeda nyata (signifikan) pada taraf $5 \%$, tn $=$ tidak nyata

Hasil analisis ragam pada Tabel 1 menunjukkan perbedaan yang signifikan terhadap luas area lubang yang terinfeksi antara perlakuan ukuran diameter pohon gaharu dan kedalaman lubang inokulasi, sementara interaksi dari kedua perlakuan tersebut tidak menunjukkan perbedaan yang nyata terhadap luas area lubang kedua perlakuan tersebut tidak dilakukan uji lanjut BNT. Selanjutnya untuk mengetahui perlakuan diameter pohon dan kedalaman lubang inokulasi mana yang berbeda nyata terhadap luas area lubang yang terinfeksi, dilakukan uji lanjut BNT yang hasilnya disajikan pada Tabel 2 dan Tabel 3. yang terinfeksi, sehingga interaksi dari Tabel 2. Pengaruh Diameter Pohon pada Luas Area Lubang yang Terinfeksi Setelah 6 Minggu Inokulasi (Influences of tree diameters in the area of infected pits after 6 weeks of inoculation)

\begin{tabular}{|c|c|}
\hline $\begin{array}{c}\text { Perlakuan } \\
\text { Diameter Pohon }(\mathrm{cm})\end{array}$ & $\begin{array}{c}\text { Rerata Luas Area Lubang yang Terinfeksi } \\
\left(\mathrm{cm}^{2}\right)\end{array}$ \\
\hline 11,46 & $174,58 \mathrm{a}$ \\
\hline 16,56 & $137,53 b$ \\
\hline 24,20 & $135,18 b$ \\
\hline
\end{tabular}

Keterangan : rerata yang diikuti dengan huruf yang sama, berbeda tidak nyata pada uji BNT 5\%=3,87 
Tabel 2 hasil uji BNT menunjukkan bahwa luas area lubang yang terinfeksi berbeda nyata diantara ukuran diameter pohon. Perlakuan dengan ukuran diameter pohon 11,46 cm menunjukkan gaharu yang terbentuk lebih luas dengan ukuran 872,92 $\mathrm{cm}^{2}$ dibandingkan diameter pohon 16,56 $\mathrm{cm}$ seluas $687,66 \mathrm{~cm}^{2}$ dan $24,20 \mathrm{~cm}$ seluas $675,89 \mathrm{~cm}^{2}$. Hasil analisis ini mengindikasikan bahwa ukuran diameter pohon 11,46 cm merupakan perlakuan yang terbaik terbentuknya gaharu pada pohon gaharu, sementara itu pada perlakuan ukuran diameter pohon $16,56 \mathrm{~cm}$ dan $24,20 \mathrm{~cm}$, menunjukkan perbedaan tidak nyata. Ukuran diameter $11,46 \mathrm{~cm}$ merupakan pohon yang ukurannya lebih kecil dibandingkan dengan ukuran 16,56 $\mathrm{cm}$ dan 24,20 cm, sehingga diduga mengandung zat ekstraktif yang lebih sedikit. Zat ekstraktif yang terdapat dalam kayu merupakan salah satu unsur yang dipergunakan pohon untuk mempertahankan diri dari serangan patogen. Senyawa gaharu yang merupakan bagian dari senyawa fitoaleksin, adalah senyawa yang dibentuk tanaman sebagai respon pertahanan pohon terhadap adanya gangguan, baik fisik, kimia maupun biologi (Michiho et al. 2005). Selain itu terbentuknya gaharu yang lebih luas merupakan petunjuk bahwa tanaman mengalami akumulasi metabolit sekunder sebagai respons atas pelukaan dan infeksi patogen (Santoso dkk, 2007). Luas infeksi yang terbentuk sebagai gejala awal yang timbul akibat adanya seranggan agen biotik dan abiotik. Hal tersebut diduga bahwa luasan infeksi yang terlihat adalah jejak infeksi yang sempat meluas, tetapi sebenarnya tanaman sudah masuk ke tahap pemulihan dimana infeksi patogen telah terhenti sehingga tanaman tidak memproduksi senyawa metabolit sekunder. Hal ini terlihat dari perkembangan luas infeksi gubal gaharu yang terbentuk, untuk jelasnya perbedaan luas infeksi diameter pohon dilihat pada Gambar 2.

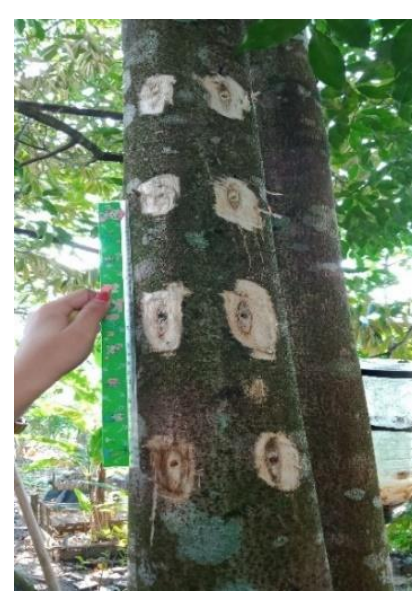

(a)

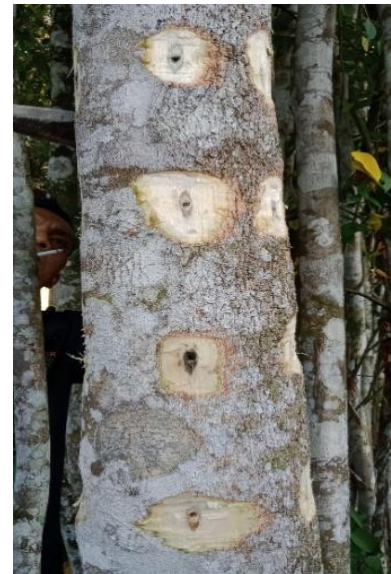

(b)

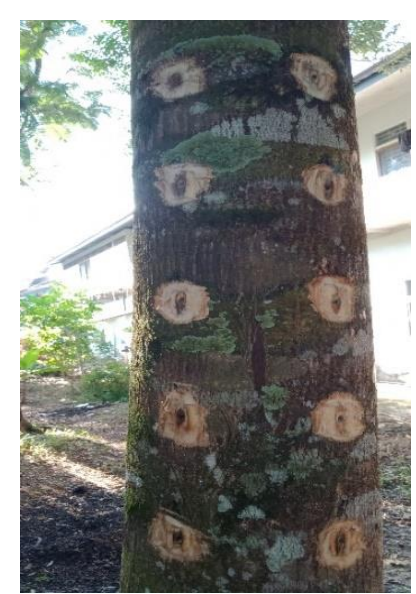

(c)

Gambar 2. Perbedaan Pembentukan Gubal Gaharu Antara Diameter Pohon 11,46 cm (a), Pohon Diameter 16,56 cm (b), dan Pohon Diameter $24,20 \mathrm{~cm}$ (c) (Difference in the formation of agarwood sapwood between the diameter of the tree $11,46 \mathrm{~cm}(a)$, the tree diameter of $16,56 \mathrm{~cm}(b)$, and the tree diameter of $24,20 \mathrm{~cm}(\mathrm{c}))$ 
Hasil penelitian ini memperlihatkan bahwa diameter pohon sangat berperan dalam mempercepat terbentuknya resin gubal gaharu dan hasil penelitian ini juga menunjukkan bahwa ukuran diameter pohon yang digunakan dalam penelitian ini sudah memenuhi persyaratan untuk dilakukan inokulasi. Selain ukuran diameter tersebut, pohon yang digunakan untuk penelitian dalam kondisi subur dan sehat setelah dilihat dari kondisi batang dan daunnya serta berumur lebih dari 5 tahun. Selanjutnya dilakukan uji BNT pengaruh kedalaman lubang inokulasi terhadap luas area lubang inokulasi pohon gaharu yang terinfeksi. Hasil uji tersebut disajikan pada Tabel 3.

Tabel 3 hasil uji BNT menunjukkan bahwa luas area lubang yang terinfeksi berbeda nyata diantara perlakuan kedalaman lubang inokulasi. Perlakuan dengan kedalaman lubang inokulasi 3 $\mathrm{cm}$ membentuk gaharu lebih luas 485,13 $\mathrm{cm}^{2}$, sementara dengan kedalaman lubang inokulasi $4 \mathrm{~cm}$ dan $5 \mathrm{~cm}$, luas gaharu terbentuk hanya seluas 451,38 $\mathrm{cm}^{2}$ dan 470,22 $\mathrm{cm}^{2}$, serta kedalaman lubang inokulasi $1 \mathrm{~cm}$ hanya membentuk luas gaharu 393,29 $\mathrm{cm}^{2}$ dan kedalaman lubang inokulasi $2 \mathrm{~cm}$ membentuk luas gaharu 436,46 $\mathrm{cm}^{2}$. Hal ini dikarenakan ada hubungannya juga dengan kandungan zat ekstraktif yang terdapat pada bagian kayu yang merupakan daya tahan tanaman terhadap serangan patogen. Pada kayu teras yang berada di dalam kandungan zat ekstraktifnya lebih tinggi dibandingkan kayu gubal yang berada di luar, sehingga pada kedalaman yang lebih dalam daya tahannya lebih tinggi. Tidak adanya pengaruh interaksi antara ukuran diameter pohon dan kedalaman lubang inokulasi ini mengindikasikan bahwa untuk pembentukan gubal gaharu dengan kedalaman lubang inokulasi $3 \mathrm{~cm}$ dapat dilakukan terhadap pohon berdiameter $11,46 \mathrm{~cm}$ ke bawah.

Tabel 3. Pengaruh Kedalaman Lubang Inokulasi pada Luas Area Lubang yang Terinfeksi Setelah 6 Minggu Inokulasi (Effect of inoculation hole depth on infected hole area after 6 weeks of inoculation)

\begin{tabular}{cc}
$\begin{array}{c}\text { Perlakuan } \\
\text { Kedalaman Lubang }(\mathrm{cm})\end{array}$ & $\begin{array}{c}\text { Rerata Luas Area Lubang yang Terinfeksi } \\
\left(\mathrm{cm}^{2}\right)\end{array}$ \\
\hline $1 \mathrm{~cm}$ & $131,1 \mathrm{a}$ \\
$2 \mathrm{~cm}$ & $145,49 \mathrm{~b}$ \\
$4 \mathrm{~cm}$ & $161,7 \mathrm{~d}$ \\
$5 \mathrm{~cm}$ & $150,46 \mathrm{cb}$ \\
$3 \mathrm{~cm}$ & $156,74 \mathrm{dc}$ \\
\hline Uji Duncan 5\% $=\quad 6,61$ & \\
\hline Keterangan : rerata yang diikuti dengan huruf yang sama, berbeda tidak nyata pada uji BNT 5\%=6,61
\end{tabular}




\section{Warna}

Tingkat warna menunjukkan gejala perubahan fisik di sekitar lubang inokulasi. Perbedaan warna gaharu yang terbentuk sekitar lubang inokulasi dilakukan dengan pemberian nilai skoring. Hasil warna gaharu yang terbentuk pada setiap perlakuan dapat dilihat pada Gambar 4. Perbedaan warna gaharu yang terbentuk berdasarkan sistem skor 1-3 dapat dilihat pada Gambar 3

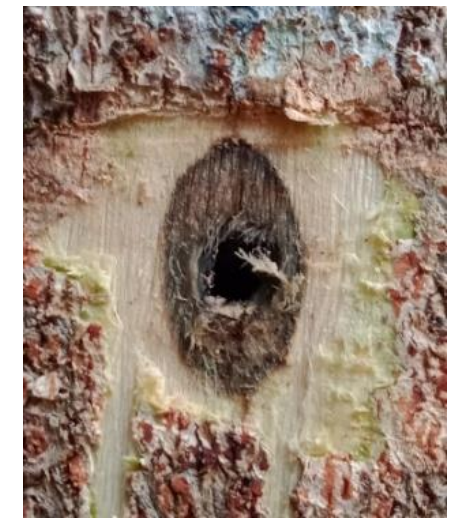

(a)

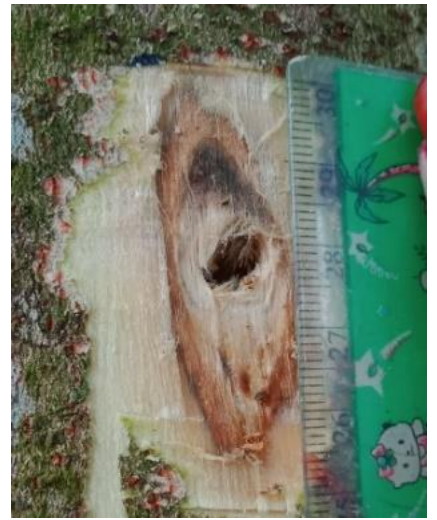

(b)

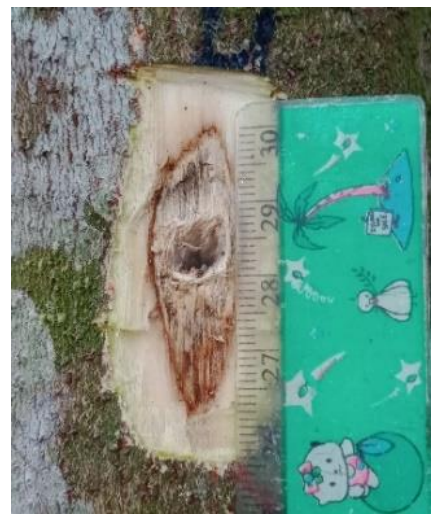

(c)

Gambar 3. Warna Berdasarkan Sistem Skor 3= Coklat Kehitaman (a), 2= Coklat (b), 1= Putih Kecoklatan (c) (Color based on score system $3=$ blackish brown (a), 2 = brown (b), 1 = brownish white $(c)$ )
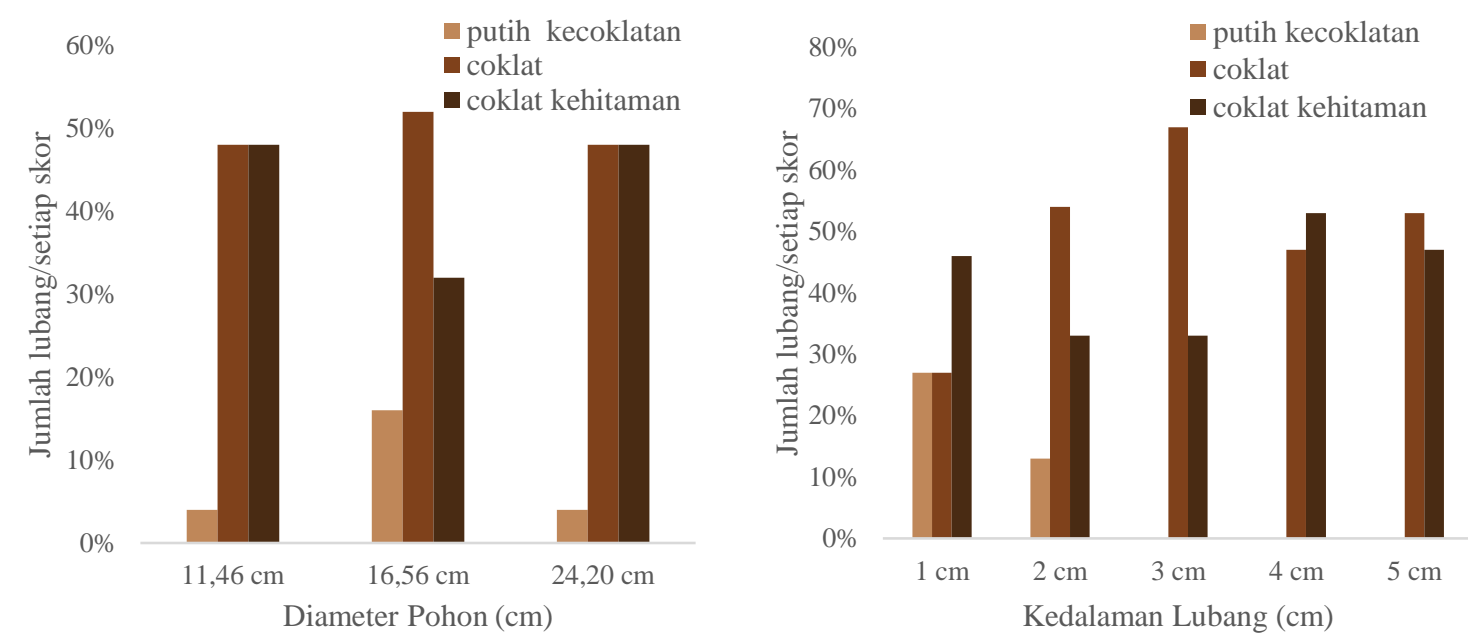

Gambar 4. Grafik Warna Gaharu yang Terbentuk Berdasarkan Ukuran Diameter Pohon dan Kedalaman Lubang Inokulasi (Color of agarwood formed based on the of the tree and the depth of the inoculation hole)

Berdasarkan Gambar 4 tersebut bahwa jumlah lubang yang berwarna putih kecoklatan (skor 1) jumlahnya sebanyak $6(8 \%)$ lubang dari 75 lubang, sementara warna coklat (skor 2) sebanyak $37(49,33 \%)$ lubang, dan warna coklat kehitaman (skor 3) sebanyak $32(42,67 \%)$ lubang. Dari hasil 
penelitian tersebut ternyata warna gaharu yang terbentuk paling banyak yaitu pada warna coklat (skor 2) dan warna coklat kehitaman (skor 3) dibandingkan dengan warna putih kecoklatan (skor 1). Berdasarkan perlakuan diameter pohon jumlah lubang pada warna coklat (skor 2) yang terdapat pada diameter $11,46 \mathrm{~cm}$ sebanyak 12 (48\%), diameter 16,56 cm sebanyak 13 (52\%), dan diameter $24,20 \mathrm{~cm}$ sebanyak 12 (48\%), ini berarti bahwa pada warna coklat (skor 2) terbanyak pada diameter $16,56 \mathrm{~cm}$ dan pada warna coklat kehitaman (skor 3) pada diameter 11,46 $\mathrm{cm}$ dan 24,20 cm. Berdasarkan perlakuan kedalaman lubang inokulasi ternyata pada warna coklat (skor 2) yang terbanyak yaitu pada kedalaman lubang inokulasi $3 \mathrm{~cm}$ sebanyak 10 (66,67\%). Ini bearti bahwa warna coklat (skor 2) lebih banyak terbentuk pada perlakuan diameter $16,56 \mathrm{~cm}$ dan kedalaman lubang inokulasi $3 \mathrm{~cm}$.

Terjadinya perubahan warna pada gaharu yang terbentuk sebagai akibat infeksi jamur yang dimasukkan melalui lubang inokulasi. Lubang tersebut adalah salah satu perlukaan yang dilakukan terhadap pohon gaharu. Walker et al. (1997) mengemukakan bahwa perubahan warna disebabkan oleh serangan patogen, pelukaan dan senyawa kimia. Menurut Suboyo (2010) warna coklat sampai hitam yang terbentuk di sekitar lubang inokulasi merupakan gubal gaharu yang terbentuk akibat infeksi jamur. Pada pemberian skor warna gaharu yang terbentuk terhadap setiap perlakuan cukup bervariasi mulai dari warna putih kecoklatan (skor 1) sampai warna coklat kehitaman (skor 3). Hasil penelitian yang sama dikemukakan oleh Putri (2007) yang menunjukkan bahwa warna bisa terjadi bervariasi antara warna putih, putih kecoklatan, coklat sampai coklat kehitaman pada sekitar lubang inokulasi.

\section{Aroma}

Penentuan aroma gaharu terinfeksi yang terbentuk pada lubang gaharu berdasarkan skoring. Pengamatan tingkat aroma dalam penelitian ini dilakukan dengan mengambil serpihan kayu pada sekitar lubang inokulasi kemudian digerus bagian dalam kayu untuk diambil sampel serpihan kayu dan dibakar serta ditentukan aromanya. Skoring ditentukan berdasarkan tingkat aroma dari masing-masing perlakuan. Hasil aroma gaharu yang terbentuk pada setiap perlakuan dapat dilihat pada Gambar 5. 

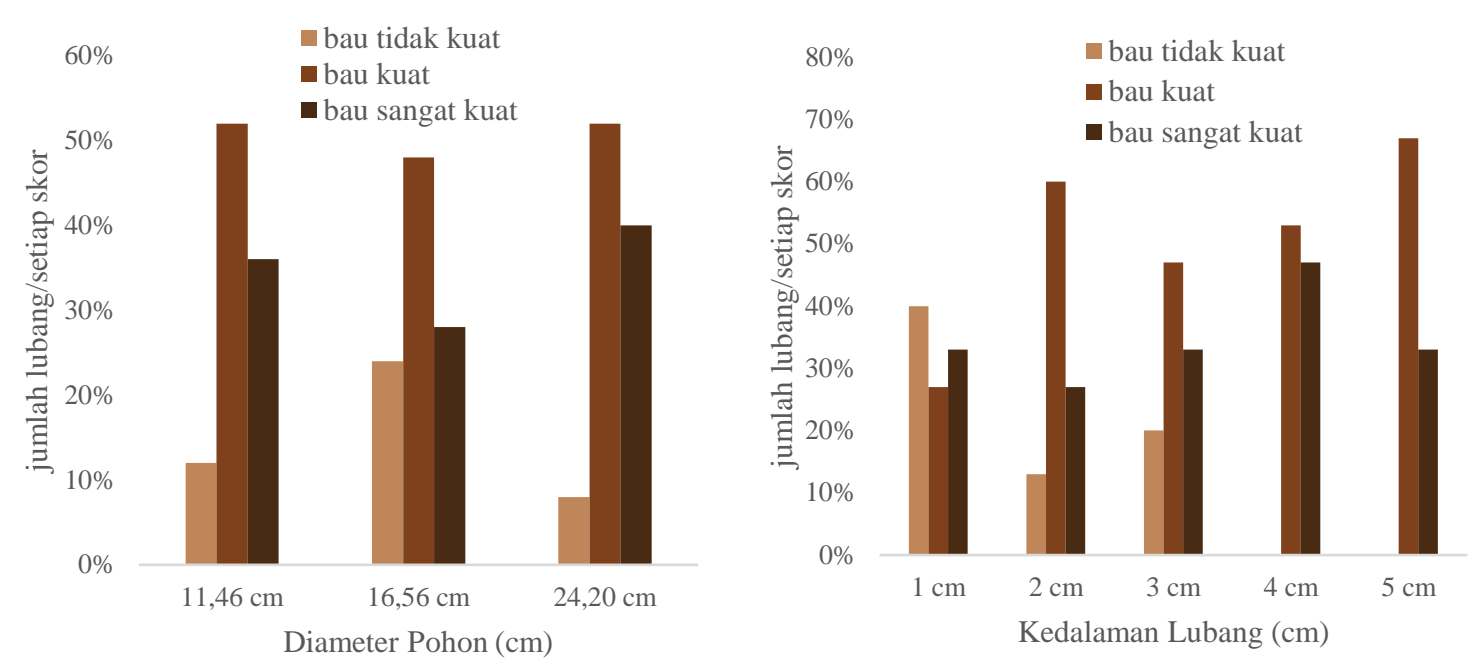

Gambar 5. Grafik Aroma Gaharu yang Terbentuk Berdasarkan Ukuran Diameter Pohon dan Kedalaman Lubang Inokulasi (Graph of agarwood aroma that is formed based on the diameter of the tree and the depth of the inoculation hole)

Berdasarkan Gambar 5 tersebut bahwa jumlah lubang yang beraroma bau tidak kuat (skor 1) jumlahnya sebanyak $11(14,66 \%)$ lubang dari 75 lubang, sementara aroma bau kuat (skor 2) sebanyak $38(50,67 \%)$ lubang, dan aroma sangat kuat (skor 3) sebanyak 26 $(34,67 \%)$ lubang. Dari hasil penelitian tersebut ternyata aroma gaharu yang terbentuk paling banyak yaitu pada aroma bau kuat (skor 2) dibandingkan dengan aroma bau tidak kuat (skor 1). Berdasarkan perlakuan diameter pohon jumlah lubang pada aroma bau kuat (skor 2) yang terdapat pada diameter $11,46 \mathrm{~cm}$ sebanyak 13 (52\%), diameter $16,56 \mathrm{~cm}$ sebanyak 12 (48\%), dan diameter $24,20 \mathrm{~cm}$ sebanyak 13 (52\%), ini berarti bahwa pada aroma bau kuat (skor 2) terbanyak pada diameter 11,46 $\mathrm{cm}$ dan diameter $24,20 \mathrm{~cm}$. Berdasarkan perlakuan kedalaman lubang inokulasi ternyata pada aroma bau kuat (skor 2) yang terbanyak yaitu pada kedalaman lubang inokulasi $5 \mathrm{~cm}$ sebanyak 10 $(66,67 \%)$. Dari kedua grafik pada Gambar 5, terlihat bahwa aroma yang kuat (skor 2) terjadi pada ukuran diameter pohon $11,46 \mathrm{~cm}$ dan $24,20 \mathrm{~cm}$ dengan kedalaman lubang inokulasi 5 $\mathrm{cm}$.

Aroma gaharu merupakan salah satu indikasi terbentuknya senyawa gaharu. Senyawa gaharu diduga merupakan bagian dari senyawa fitoaleksin. Senyawa ini dibentuk tanaman sebagai respon terhadap adanya gangguan, baik fisik, kimia maupun biologi (Michiho et al. 2005). Menurut Rahayu et al. (2009) peningkatan aroma tidak selalu diikuti dengan perubahan warna. Peningkatan aroma diduga disebabkan oleh bertambahnya senyawa sesquiterpen begitu juga penurunan tingkat aroma yang diakibatkan oleh hilangnya senyawa ini karena mudah menguap. Wahyuni dkk, (2018) mengemukakan bahwa senyawa fitoaleksin pada 
Aquilaria malaccensis yang terinfeksi cendawan pembentuk gaharu bersifat aromatik dan mendukung perubahan kayu menjadi coklat kehitaman. Selanjutnya dikemukakan oleh Hartall dkk, (2007) terjadinya perubahan warna di sekitar lubang induksi dan terbentuknya aroma wangi dari bagian yang warnanya berubah tersebut merupakan indikator terbentuknya gubal gaharu.

\section{Kesimpulan}

Hasil kajian kedalaman lubang inokulasi dan ukuran diameter pohon terhadap infeksi gaharu yang terbentuk dapat disimpulkan sebagai berikut:

1. Kedalaman lubang inokulasi $3 \mathrm{~cm}$ membentuk gaharu yang lebih luas, warna coklat, serta aroma yang kuat dan berbeda nyata dibandingkan dengan kedalaman $1 \mathrm{~cm}, 2 \mathrm{~cm}, 4 \mathrm{~cm}$ dan $5 \mathrm{~cm}$. Hasil penelitian ini mengindikasikan bahwa lubang inokulasi sedalam $3 \mathrm{~cm}$ lebih sesuai untuk inokulasi pembentukan gubal gaharu.

2. Pohon berdiameter 11,46 cm membentuk gaharu yang lebih luas, warna coklat kehitaman, serta aroma yang kuat dan berbeda nyata dibandingkan dengan ukuran diameter $16,56 \mathrm{~cm}$ dan $24,20 \mathrm{~cm}$, sementara itu antara pohon berdiameter $16,56 \mathrm{~cm}$ dan $24,20 \mathrm{~cm}$ tidak menunjukkan perbedaan luas infeksi gaharu yang terbentuk.

3. Hasil analisis keragaman, ternyata interaksi antara kedalaman lubang inokulasi dan ukuran diameter pohon tidak berbeda nyata terhadap luas area lubang yang terinfeksi pada gubal gaharu yang terbentuk.

4. Hasil penelitian menunjukkan bahwa gaharu yang terbentuk lebih banyak bewarna coklat (skor 2) pada diameter pohon $16,56 \mathrm{~cm}$ dengan kedalaman lubang inokulasi $3 \mathrm{~cm}$, sementara itu diameter pohon 11,46 $\mathrm{cm}$ dan 24,20 cm dengan kedalaman lubang inokulasi $5 \mathrm{~cm}$ membentuk gaharu beraroma kuat (skor 2).

\section{Saran}

1. Perlu dilakukan penelitian lebih lanjut terhadap pohon gaharu yang diameternya di bawah 11,46 cm dengan kedalaman lubang inokulasi $3 \mathrm{~cm}$ untuk melihat apakah hasilnya bisa lebih baik dalam mempercepat pembentukan gaharu.

2. Perlu dilakukan penelitian mengenai hubungan kandungan ekstraktif yang terdapat pada pohon gaharu terhadap volume dan kualitas gaharu yang terbentuk mulai dari ukuran diameter pohon yang terkecil.

3. Perlu dilakukan penetapan standar kualitas gaharu yang memiliki nilai ekonomi untuk diperdagangkan.

4. Pengamatan terhadap gaharu yang terbentuk perlu dilakukan dengan waktu yang lebih dari 3 bulan agar dapat diketahui kualitas dan volume gaharu yang terbentuk.

\section{DAFTAR PUSTAKA}

Anonim. 2007. Permenhut No P.35/Menhut-II/2007 tentang Penetapan jenis-jenis HHBK. Departemen Kehutanan RI. Jakarta.

Hartal dan Anwar G. 2007. Teknologi Peningkatan Kualitas Kayu 
Gubal Gaharu (Aquilaria malaccensis Lamk.) di Kawasan Pesisir Bengkulu dengan Inokulasi Jamur Penginduksi Resin. Jurnal Ilmu-Ilmu Pertanian Indonesia. $3: 464$ 471.

Michiho I. 2005. Introduction of Sesquiterpenoid Production by Methyl Jasmonate in Aquilaria sinensis Cell Suspension Culture. Essential Oil Research. http/www.findarticles.com ( 1 September 2019).

Mucharromah. 2010. Pengembangan Gaharu di Bengkulu, Sumatera (The Development of Agarwood in Bengkulu, Sumatra). Info Hutan; 8 (2) : 117-128.

Muin A, Burhanuddin, Muin S. 2017. Teknik Budidaya Tanaman dan Induksi Pembentukan Resin Aromatik Gubal Gaharu. Pontianak. Untan PRESS".

Putri A. 2007. Induksi Pembentukan Wangi dan Senyawa Terpenoid pada Pohon Gaharu (Aquilaria crassna) dengan Acremonium sp. dan Metil Jasmonat (MeJA). Bogor. Fakultas Matematika dan Ilmu Pengetahuan Alam, Institut Pertanian Bogor.

Rahayu G, Santoso E, Wulandari E. 2009. Efektivitas dan Interaksi Acremonium sp. dan Fusarium sp. dalam Pembentukan Gubal Gaharu pada Aquilaria microcarpa. Kumpulan Makalah Workshop Pengembangan Teknologi Berbasis pada Pemberdayaan Masyarakat di Sekitar Hutan, tanggal 29 April 2009. Kerjasama Pusat Penelitian dan Pengembangan Hutan dan
Konservasi Alam Dengan ITTP PD 425/06 Rev. 1 (I).

Rahayu G, Santosa E, Ririn FW. 2009. Pengaruh Etilen dalam Menginduksi Pembentukan Senyawa Terpenoid pada Pohon Gaharu (Aquilaria microcarpa). Departemen Biologi Fakultas Matematika dan Ilmu Pengetahuan Alam Institut Pertanian. Bogor.

Sumadiwangsa S, Zulnely. 1999. Catatan Mengenai Gaharu di Kalimantan Timur dan Nusatenggara Barat. Info Hasil Hutan 5 (2) : 80-90.

Santoso E, Agustini L, Sitepu I, Turjaman M. 2007. Efektivitas Pembentukan Gaharu dan Komposisi Senyawa Resin Gaharu pada Aquilaria spp. Jurnal Penelitian Hutan dan Konservasi Alam 4 (6) : 543-55.

Siran SA. 2010. Pengembangan Teknologi Gaharu Berbasis Pemberdayaan Masyarakat. Pusat Penelitian Sekitar Hutan. Bogor.

Suboyo YB. 2010. Jamur Pembentuk Gaharu Sebagai Penjaga Kelangsungan Hidup Tanaman Gaharu (Aquilaria sp.). Jurnal Tek. Ling 11 (2) : 167-173.

Try FYS, Muin A, Idham M. 2017. Pengaruh Diameter Pohon dan Jarak Lubang Inokulasi Terhadap Pembentukan Gubal Gaharu pada Tanaman Aquilaria Malaccensis Lamk. Jurnal Hutan Lestari 5 (2) : 200-208

Walker D, Taylor RW, Mulrooney RP. 1997. Diagnosing Field Crop Problems. 
http://ag.udel.edu/extension (diakses : 01 September 2019).

Wahyuni R, Tridiati T, Falah S. 2018. Induksi Pembentukan Gaharu Aquilaria Malaccensis Menggunakan Pupuk Urea Fusarium Solani. Jurnal Penelitian Kehutanan Wallacea 7 (2) : 165-171.
Zhang Z, Wei J, Han X, Liang L, Yang Y, Meng H, Xu Y, Gao Z. 2014. The Sesquiterpene Biosynthesis and Vessel-Occlusion Formation in Stems of Aquilaria Sinensis (Lour.) Gilg Trees Induced By Wounding Treatments Without Variation of Microbial Communities. International Journal of Molecular Sciences 15 (12) : 23589-23603. 